\title{
Human Security and the Israel-Palestine Conflict: External vs. Internal Perspectives
}

\author{
Nadia Baranovich \& Ravichandran Moorthy
}

\begin{abstract}
The formation of the State of Israel in 1948 has led to bloody course of events, which continues to this day, as to who has the right to claim the land home; the Palestinian-Arabs (mostly Muslim) or the Jewish (mostly non-Arab residents). The Israel-Palestine conflict is one of the most violent and bloodiest protracted conflict in the post World War II era, which has resulted in massive human casualties and human rights abuses for decades. The numerous wars in conjunction with the rise of militant groups like Hezbollah and Hamas have led to the development of a human security dilemma in Palestine and Israel. Decades of violence and destruction have resulted in massive human casualties, political chaos and disruption to the way of life of the people in the region. The concept of human security began to enter mainstream human rights, security and international politics debate, more prominently, after the release of the 1994 report United Nations Development Programme (UNDP) report on Human Development. The report is essentially explicit manifestations of the human rights principles enshrined in the 1948 United Nations Declaration of Humans Rights (UNDHR). Human security pushes for intense promotion and greater respect for human life in all spheres of human endeavors. This article inspects the human security dimension present in the Israel-Palestine conflict. This article encompasses two major parts. The first part provides an external understanding of how human security principles can be applied to IsraelPalestine conflict and how it affects the possibility of peace. Secondly, the article addresses the question on how people 'inside' the conflict view human security and the possibility of peace.
\end{abstract}

Keywords: Human Security, Peace, Violence, Terrorism, IsraelPalestine conflict 
Human Security and the Israel-Palestine Conflict:

\section{Introduction}

Wars, conflicts and destructions have become synonym with the history of man. The last century has witnessed two world wars and numerous bloody conflicts fought over ideologies, beliefs, ethnicity, territory and resources. These conflicts have resulted in massive human casualties. The inability of the states and the international systems to address this situation prompted human rights thinkers and analysts to device concepts and instruments for the promotion of a safer world for humans. This eventually gave birth to the concept of human security. The Israel-Palestinian conflict is perhaps one of the bloodiest and longest conflicts known to humans. It is caused by a wide variety of factors ranging from the historical memory of violence, disputes over the control of land,

- contradictory historical accounts, religious animosity and continuous mistrust with one and another. These factors have resulted in massive human security dilemmas in this region. The conflict has been further exacerbated by terror activities by militant groups like the Hezbollah and Hamas in support of the Palestinians. As a reactionary measure, the Israelis engage in massive counter strikes targeting both military installations and civilian populations, which bring about disruption and destruction to Palestinian lives and - properties. Decades of violence have left the Palestinian community devastated with massive civilian casualties, restriction on free movement of people and denied access to basic necessities and international humanitarian aid. On the other hand, for the Israelis, they have found themselves having to live their lives, go to school, commute to work, and raise families in the shadow of terror (Israel Ministry of Foreign Affairs, 2001). Thus combating terrorism has become their primary national security concern. Acts of terror are being fought at all fronts.

-

\section{Human Security Debate}

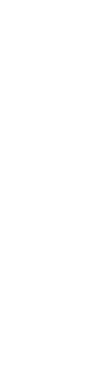

Human security is an emerging paradigm for understanding global vulnerabilities whose proponents challenge the traditional notion of national security by arguing that the proper referent for security should be the individual rather than the state. Human security holds that a people-centered view of security is necessary for national, regional, and global stability. Human security pushes for intense promotion and greater respect for human life in all spheres of human endeavors. Although, this concept began to manifest occasionally in the nine decades of the $20^{\text {th }}$ century, it was only after the release of the 1994 United Nations Development Programme (UNDP) report on Human Development that the concept began to enter mainstreams human rights, security and in international political debates, more prominently. This report expanded the focus coverage of the concept to include seven aspects namely economic security, food security, environmental security, personal security, community security, political security, and health security (Acharya, 2008). In addition, human security also includes safety from chronic threats such as hunger, disease, and repression, as well as protections from sudden and harmful disruptions in the pattern of daily lives. Further, in more recent scholarship, the concept has been stretched to include economy, health and environmental concerns. The present classification of human security now includes a radically expanded coverage of issues, 
far surpassing the limited coverage in the post Cold War period. The concept of human security also captures and further clarifies the spirit of the major principles of human rights that are enshrined in the 1948 Universal Declaration of Human Rights (UNDHR).

Faber (2008) notes that there are two competing schools of human security. The first one is focused on "freedom from want" which is about addressing the basic needs of humans as highlighted by the United Nations seven areas of focus for human security. The second school of human security addresses "freedom from fear", i.e. removing the use of threat, of force and violence from the everyday lives of communities. All proponents of human security agree that the primary goal is the protection of individuals; however, precisely what threats individuals should be protected from is where the consensus breaks down.

- The promotion of this concept has drawn mix reactions from states in different region of the world. There has been skepticism about the need for such concept in view of the continuing move in different parts of the world to improve democratic processes and expand the meaning of this concept, thus improving the overall human security. Secondly, views between East and the West on what this human security really means or should mean and in what sort of issues it should cover, appears to be divergent. In fact - many in the East see human security as an alien Western centric model, which does not really take into account Eastern sentiments and values. Some even assert that the concept is a Western prescription for the lack democracy in the East. More intense debate began to take place in an attempt define and redefine 'human security' in the post Cold War era. However, much of the debate focused on the perennial problem of differing cultures and sometimes contradicting values embraced in the West and the East, which gave rise to the difficulty in coming up with some form of common explanation(s) to this concept.

"

()

Current debates on human security issues have somewhat transcended the traditional realpolitik perspective. However, this concept still draws different and rather varied - interpretations, since it emerged on several occasions during historical changes,
especially in the period after the Second World War. From the traditionalist perspective, the state is seen as the 'central unit of analysis' and 'security commensurate with national survival within the world that is inherent contentious and anarchical' (Tow \& Trood, 2000). Thus, the core tenet of discussion from the traditionalist standpoint is that 'security' is very much related to 'national security'. Thus, preserving national security seems to be the core principle of nation state, while human and his security, although important, remains an auxiliary prerequisite to further reinforce national security. While this may be true, there have been also calls to expand the scope of human security. For example, Kofi Annan, in his call for a broadening of ideas about peace and security, stresses that human security can no longer solely have a military meaning; it is also a matter of human rights, of good governance and must encompass economic development, social justice, environmental protection, democratization, disarmament, and respect for human rights and the rule of law (Annan, 2001).

Human security prescribes a holistic notion of security as opposed to the traditional state centric notion of security. At the core, human security focuses on the welfare of the people within a state society. Having established the goal, the next question is what are 
the proponents that can properly assist human security to achieve its rather expanded role. Unlike human rights, which have been based on correlative duties, the concept of human security is not necessarily been coupled with obligations. This is perhaps because there is no normative document that has come out from the debate, other than the 1994 report. Secondly, perhaps this is due to its non-state centric nature, where states become somewhat cautious in embracing its principles. However, the idea behind the human security approach is to transform traditional notions of security away from the focus of national and regional stability of political and economic systems to focus on human beings. Thus, primary threats are seen as internal and no longer the exclusive domain of military forces. Such internal threats include economic failure, the violation of human rights, and political discrimination. Therefore, the guarantee of national security is in - favorable social, political and economic conditions, the promotion of human development, and the protection of human rights as opposed to solely relying on military power (Tadjbakkhsh, 2005).

\section{(1) Methodology}

-

This article covers two main parts. The first part discusses the external perspective on how human security principles can be applied to Israel-Palestine conflict and how it affects the possibility of peace. While, the second part addresses how people 'inside' the conflict view human security and the possibility of peace. For the first part, the authors use document analysis and theoretical discussion based on the normative documents of human security, which includes discussion on the applicability of the seven principles in - the conflict dynamics. For the second part, the authors utilized inputs from interviews and survey of relevant respondants from the conflict region. Essentially, this is to capture how people involved in the conflict view human security and the possibility of peace in the

region. While much research has been done analyzing the Israel-Palestine conflict, little
of the research has directly explored the feelings and perceptions of those within the a conflict zone itself. In addition to document analysis, the discussion in this section incorporates feedbacks and opinions from respondents based on interviews. In an effort to provide an internal perspective of the conflict, interviews were conducted with the Palestinian Ambassador attached to the Palestinian Consulate in Kuala Lumpur and with the Deputy Chief of Mission at the Israeli Embassy in Singapore. A questionnaire was also drafted and distributed to individuals from Palestine and Israel. The survey primarily deals with gathering perceptions and opinions about how 'insiders' view the human security dilemma and the proposed two-state solution, as well as the differences that may exist between the government and civilian perspectives.

The survey consists of three different parts: a demographic section, a human security section, and a section regarding the opinions of the two-state solution proposal. The demographic portion of the survey included information such as the respondent's gender, age, ethnicity, citizenship/residence, religion, and education level. The purpose of the demographic portion was to help provide information on the background of the respondents. The total number of Palestinian survey respondents was 32 with 78.1 
percent being male and 21.9 percent female, between the ages of 18 and 41 . Approximately 87.5 percent of the respondents held Palestinian citizenship while the remaining 12.5 percent held a refugee status in a foreign country, and 96.9 percent identified themselves as being Muslims and 3.1 percent with Christianity. The education level of the respondents ranged from a secondary education level to a doctoral degree, with the majority holding a university post graduate qualifications. The total number of Israeli respondents is 21 , ranging between the ages of 18 and $65,33.3$ percent of which were male and 66.7 percent were female. The education level of the respondents ranged from a university undergraduate degree to doctorate degrees. All respondents identified themselves with the Jewish religion.

- The human security portion of the survey focused on analyzing the individual's view of human security. The survey questions were designed to gain an understanding of whether or not the respondents felt there was a human security situation existing in their community, what factors they thought accounted for it, what daily security concerns they had, and what level of trust they had in their respective government/political organizations, and civilian neighbours. This is an important section of the survey as it is instrumental in providing insights as to how individuals on the inside think and feel of the situation. The final section of the survey was designed to understand the respondent's views of the two-state solution. The focus was on determining if the respondents felt that the two-state solution was a viable option or not and what factors accounted why or why not. This section was included in order to understand how the respondents felt about the proposed peace plan and the human security situation in the framework of the peace plan.

\section{Human Security in the Israel-Palestine Conflict: An External Perspective}

This section discusses why human security is relevant to the Israel-Palestine conflict and how it affects the possibility of peace in this region, as viewed by researchers. Although human security garnered much attention of international scholars following the end of the Cold War, yet it has failed to be properly analyzed with regards to the Israel-Palestine conflict. One could easily question the applicability of such a concept in conflict zones since its very use in peaceful times appear to be problematic. While this perception may hold to be true, the rampant human rights abuses in these zones make it even more pertinent for human security principles to be advocated more vigorously. Ideally, individuals and communities should have the ability to live securely within states with secure borders, which is not possible in conflict areas. In the context of the IsraelPalestine conflict, where there exist militant actions, occupation, and annexation, where there are no clearly defined borders, and a high level of individual and community fear, the human security paradigm provides a useful view in examining the consequences of this conflict as it relates to those involved. In fact, shifting the security reference from that of a state-centric view to a human-centric view is particularly appropriate in the case of the Israel-Palestine conflict, given that in this situation there is much chaos and military conflict. The role of non-state militant actors has further exacerbated the conflict and has led to much infrastructure destruction and the loss of Palestinian autonomy, as it 
becomes occupied by Israel. This situation has refueled the cycle of hate, violence, and instability in the region, with other neighbouring countries getting involved in the conflict. From an external viewpoint, i.e. one posited by those not party to the conflict, the human security situation existing within Palestine and Israel can be directly attributed to the cycle of terrorism and military conflict exhibited by Hamas, and other Palestinian factions, as well as by Israeli forces. This is further fueled by the consistent failures of the peace talks.

The concept of the two-state solution calls for the creation of two separate states, one Jewish and the other Arab, as a way to resolve the Israeli-Palestinian conflict. Ironically the two-state solution, which has been under negotiation since the 2002 road map for - peace, ${ }^{1}$ closely resembles the original partition plan as established by the United Nations in 1947 . In contrast to the 1947 two-state partition, the 2002 two-state solution calls for a return to the partition existing in 1967 via the green line. ${ }^{2}$ The renewed fever for the twostate solution has become a crucial issue in the Israeli-Palestinian conflict. The 1949 green line's existence has thus come to play a key role for the boundaries of a future Palestinian state. The two-state solution is quite relevant to the discussion of human - security in Palestine, and Israel, as for the most part the human security dilemma is recognized as being linked, or rooted, to the Israel-Palestine conflict. Following the 1993 Oslo Accords, the two-state solution, as an official peace plan policy has been cited as the only policy which will be able to provide both peace and stability to the Palestinians and Israelis, and to the region with regards to this conflict. Therefore, the running belief behind the two-state solution is the assumption that by successfully creating two separate states (one Palestinian and one Jewish) then the conflict will end, alleviating the state - security and human security dilemma resulting from the conflict.

\section{Palestinian Scenario}

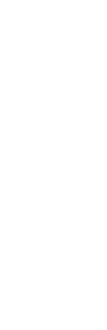

Since the 1948 war the Palestinians have faced a growing concern with human security. The post 1948 wars have led to a loss of Palestinian autonomy that has resulted in an unstable government, particularly seen in the ongoing conflict between Hamas and Fatah, both of which are political parties under the Palestinian Liberation Organization (PLO). In addition, different official security forces are competing for political power as opposed to working on maintaining law and order. This absence of official law and order has led to a vacuum where political factions, criminal gangs, and armed families work to take matters into their own hands. The existence of armed families, looking out to ensure their survival, has a tendency to use their weapons as a source of income via partaking in kidnapping or hostage taking (Faber \& Kaldor, 2007). Apart from government instability, the human security dilemma present in Palestine extends to personal security, community security, economic security, food security, health security and environmental security. In the case of Palestine, economic, health and food insecurity can be viewed as being highly correlated with the community insecurity; and personal insecurity as an outcome of community insecurity. Environmental security is also important, as it is closely associated with health security of Palestinians. Much solid waste and sewage water is 
being dumped openly in small towns and cities, which have caused both the water and air have become polluted which directly affects the health of Palestinians.

With regards to community and personal security, the biggest threats, from an external viewpoint, facing the Palestinian people is the lack of permanent settlement that they face. Israel's land gains through wars, and other means, have resulted in many Palestinians being uprooted from the homes. Further, Israel's heavy emphasis on military force has led to much destruction of Palestinian homes and infrastructure, such as the December 2008 Gaza conflict. The devastation of infrastructure in conjunction with the land losses has resulted in a health, food, and economic insecurity situation, which got worse when supplies were cut off from reaching the Palestinians. Naruse (2009) has - noted that since the 2000 Intifada the Palestinian economy has declined year by year, with a current unemployment rate of more than 60 percent causing many Palestinians to live below the poverty line. This has further underscored their ability to meet their basic needs, such as food and medical care. Naruse further posited that the conditions existing on the Gaza Strip, post December 2008 conflict, have caused the community existing there to enter into a cycle of conflict as individuals compete to have their basic needs met.

\section{Israel Scenario}

Unlike Palestine, the external human security view of Israel recognizes the major threats as being community and personal security. It can be accurately stated that since Jewish

- adherents began migrating to what is now Israel, under the banner of Zionism, personal security was not always felt. Much tension between them and the Palestinians erupted over their presence in what it is considered 'Arab' land, and then the subsequent - formation of the State of Israel put community security in question due to the hostile attitudes felt by their neighbours over their existence, which resulted in numerous wars. - Though Israel is more often than not the victor of these wars, the security of the civilian population is questioned in the sense that the wars are more often than not responses to missile launching and suicide bombing which infiltrate Israeli communities. Figure one shows that between 2001 and 2007 some 8,341 people, both civilian and security forces were wounded in the conflict. Figure two shows that in the same period, some 140 suicide bombing attacks occurred, with 542 casualties. 


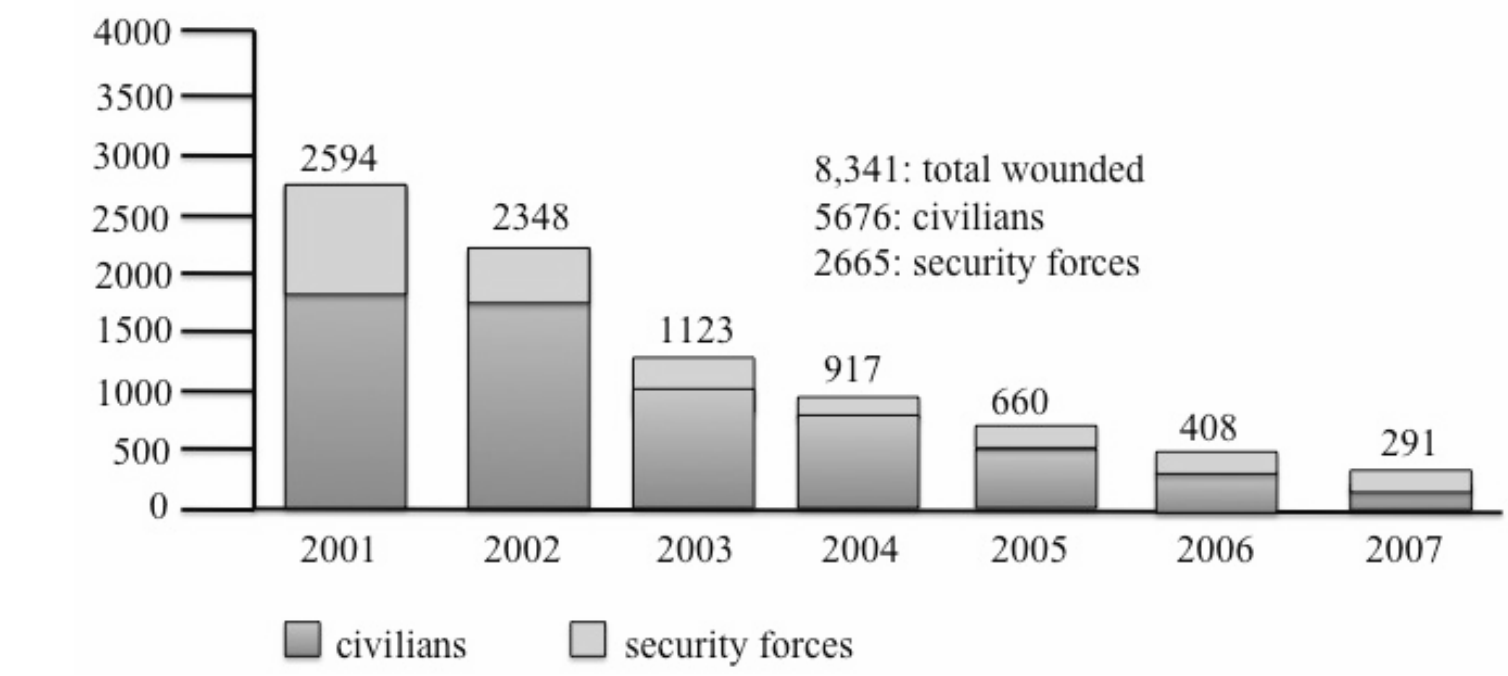

C) Figure 1: Graph depicting statistics on Israeli's wounded in terror attacks from - 2001-2007. Source: Israel Ministry of Foreign Affairs.

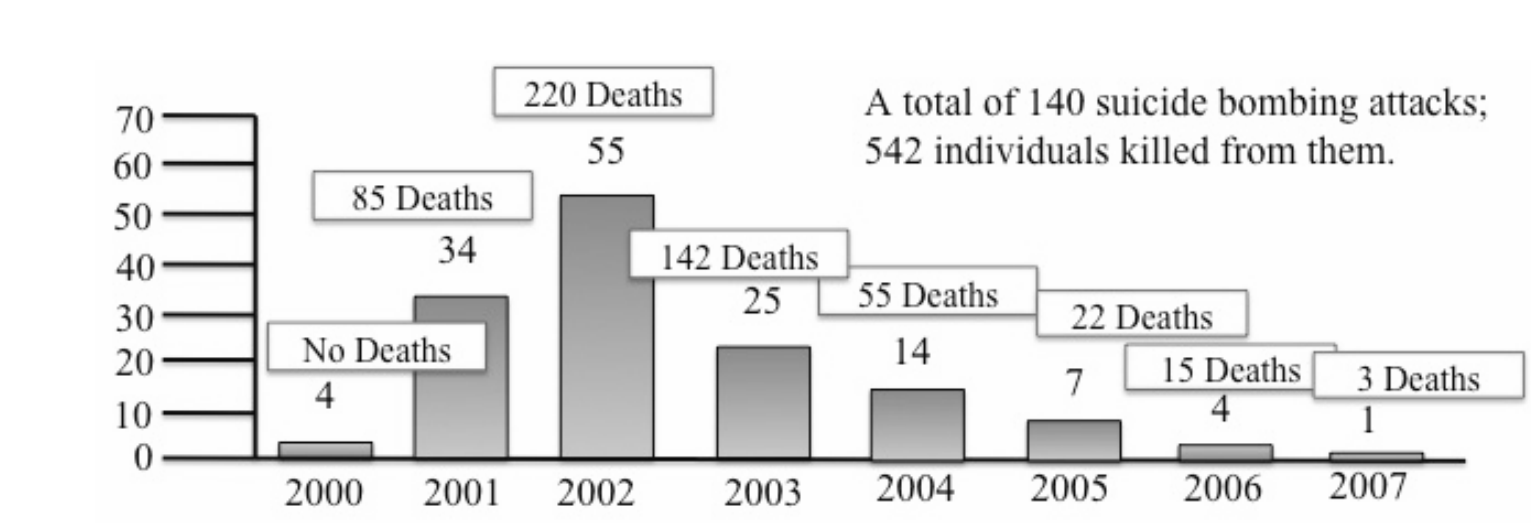

Figure 2: Graph depicting statistics on the number of suicide attacks from 20002007. Source: Israel Ministry of Foreign Affairs.

While the use of missile rockets and suicide bombings along border areas, and inside Israeli towns, have no doubt jeopardized the security of Israelis, it is necessary to note that the excessive use of force utilized by Israel in response to the attacks have further aggravated the problem. As anger and hatred are reignited in the midst of attacks, and the thought that Israel disregards the rights of the Palestinians to exist, a perpetual cycle of hate, distrust, and violence is instigated. 


\section{Human Security in the Israel-Palestine Conflict: An Internal Perspective}

\section{Palestinian Scenario}

\section{(a) The Government ${ }^{3}$}

The human security situation for Palestine revolves primarily around the absence of an autonomous homeland. According to Ambassador Aboughosh, Palestinian Consulate in Kuala Lumpur, from the governments perspective, Palestinian's view Israel as that of an occupier, and feelings of insecurity arise from the continuation of settlement building, the existence of border walls, Israel's disregard for U.N. Resolutions, and their inhumane practices against the Palestinians, which take the form of unfair taxation, residence and building licenses. He further posits that the Palestinian human security situation affects only the personal and community security, and that the major concern for Palestinians in their daily life is the absence of a guaranteed home. Thus all Palestinians are united in their opposition of Israel and in the goal of ending the occupation. This narrow view of Palestine's human security situation differs from that of scholars who typically view Palestine's human security situation on all seven aspects identified by the United Nations.

The Palestinian government views neighbouring countries as being helpful to their plight, especially in terms of monetary aid. However, while the general idea is that Hamas serves the role of the white knight for the Palestinians on the Gaza Strip, within the government there is a contradictory view. They see Hamas as acting illegally as the political representation of Gaza, and their actions work to hurt the Palestinian cause. As Aboughosh claims, Hamas seized power by force and destroyed Gaza's institutions to legitimize their position. They are further seen as hurting the Palestinian cause by placing an emphasis on Islam, which undermines the Christian part of the Palestinian community who suffer the same fate. Therefore, some within the Palestinians government feel that both Israel and Hamas are perpetrators of the conflict and the Palestinian human security problem. With regards to the two-state solution, the Palestinian government is in favor of negotiating with Israel a return to the 1967 borders. There is a high belief that the creation of two-states can bring an end to the conflict and can help in reducing terrorist tensions in the region. On their part, the Palestinian government feels they are doing everything in their power to make the two-state solution a reality by applying the road map; yet the view from them is that Israel does not want to have peace, which is why they continue to disregard the road map by failing to freeze settlement activities and restricting the movements of the Palestinians.

\section{(b) The People}

With regards to human security dilemma existing within Palestine, not all of the Palestinian respondents felt that their community faced a human security problem, but all of the Palestinian respondents indicated that the Israeli government, Israeli individuals, and that State of Israel itself presented a threat to their community. 
Further 46.9 percent of the Palestinian respondents felt that Jewish adherents in general posed a threat to the Palestinian community. Though the majority of the respondents indicated that the Hamas organization did not pose a threat; yet, 21.9 percent felt that they did threaten Palestinian security and 18.8 percent believed other Palestinian political groups to be a threat to their well-being. Other factors recognized as being threats and daily concerns to Palestinian security include terrorism, military actions, terrorist acts, access to medical care, and getting enough food.

In considering the likeliness of a violent conflict between Israel and Palestine within the next five years, 75 percent of the respondents indicated that a violent conflict was very likely to happen with the causes of the conflict being cultural differences between the Arabs and Israelis, unresolved status of the Palestinian territories, military actions, poverty, and missing persons. When questioned on trust, the majority of the respondents indicated no trust in the Israeli government and that they held no trust in Israeli individuals. Both factors that could further fuel another conflict. The Palestinian respondents trust for Hamas was mixed between a high level of trust and no trust in the organization. Where Palestinian civilians and neighbouring Arabs were concerned, the respondents indicated mixed levels of trust, yet the results portrayed only a mild level of trust of neighbouring Arabs.

Though the Palestinian government officially states their desire for the two-state solution to be achieved, the majority of the Palestinian respondents indicated that they did not believe the two-state solution is possible to achieve. The significant factors identified as prohibiting the two-state solution from being possible include a lack of trust in the Israeli government, a lack of trust in the Israeli people, and ideological and cultural differences between the Arabs and Israeli's. The survey shows that in considering the two-state solution as a way to end the Palestine-Israel conflict the majority of the respondents indicated that it would not help end the conflict, while the remaining respondents opinions varied from feeling that it could help bring an end to the conflict or were unsure. As to whether or not the two-state solution would reduce the tension of the conflict between Palestine and Israel there was an even split between those who felt that it would not and those who were unsure, while a small remaining percentage indicated that the two state solution may help to reduce the tension between Israel and neighbouring Arab states. Thus, from this we gain an understanding that at least some of the Palestinian populace do not hold faith in the two-state solution. More data would have to be gathered before this finding can be generalized to the Palestinian populace as a whole.

\section{Israel}

\section{(a) The Government ${ }^{4}$}

According to Edit Abu, Deputy Chief of Mission at the Israeli Embassy in Singapore, Israel has no choice but to view Hamas as a threat based on the militant actions taken by them against the State of Israel. The Israeli government view them as a threat due 
to the zero-sum attitude they hold, their location within, and bordering, Israel, and their denial of Israel's right to exist as proclaimed in their charter. The local government views Hamas as providing no room for negotiation and provides a high level of insecurity for Israel, and Israeli's, based on their high acceptance of suicide bombing and the fact that they target homes, hotels, malls, and buses in their suicide attacks. This in turn forces Israel to have to take strong military counter actions in order to attempt to end hostilities. The two state solutions has been an official policy of Israel since 1993. However, Israel needs a strong Palestinian partner that can control the Palestinian territories. Hamas has consistently worked to prevent the twostate solution from occurring as their charter disregards Israel's right to exist; which makes them a threat to Israel and to the Palestinian people. Fatah's willingness to negotiate and cooperate with Israel has led to an improved situation in the West Bank, where Fatah has the control, especially in regards to the economic situation. The situation in Gaza, however, has deteriorated as a result of conflict Hamas instigates against Israel that oppresses the Palestinian people living there (Abu, 2010).

\section{(b) The People}

Unlike the Palestinian respondents, the Israeli's surveyed acknowledged a belief in the existence of a human security problem in Israel. The factors identified as being the root of the human security dilemma include the Hamas organization, other Palestinian political groups, the Hezbollah organization, and terrorism. To a lesser extent Palestinian individuals were perceived as a factor contributing to the human security situation of Israel along with neighboring Arab states The Israeli respondents indicated that terrorist acts and military actions were a source of insecurity to their community and represented a daily concern. In considering the likeliness of another violent conflict between Palestine and Israel occurring within the next five years, all respondents indicated that the likelihood of another violent conflict was highly likely. The factors identified as being the associated causes of the conflict include military actions, the unresolved status of the Palestinian territories, and missing persons. With regards to trust, all respondents indicated that they held no trust for Hamas, and a great majority indicated no trust in the Palestinian people. As for neighbouring Arab state civilians, trust ranged from little to no trust.

When questioned on their opinion of the proposed two-state solution 47.6 percent of the survey respondents felt that the creation of two states was possible, with 52.4 percent indicating that it was not possible. The factors identified as not allowing for the two-state option to become a reality were a lack of trust in Hamas and other Palestinian political organizations, a lack of trust for the Palestinian people, a lack of trust in external states, and too much existing military tension and terrorist activity. As for those who indicated that the two-state solution was possible, they considered the abandoning of Israeli settlements from the Gaza Strip, the West Bank, and Jerusalem necessary, along with the demilitarization of the Palestinian territories and the removal of the Israeli military. When considering if the two-state solution would 
bring an end to the conflict, 47.6 percent indicated that it would end the conflict while 52.4 percent felt that it would not be able to end the conflict.

\section{Discussion}

From an external perspective it is easy to witness a human security dilemma in Palestine and Israel occurring as a result of the Israel-Palestine conflict. Interestingly though, this view is not necessarily shared by those within the communities themselves. Those surveyed from the Israel community did all feel the threat of a human security dilemma that results predominantly from Hamas's terror acts against their communities, as well as - from other Palestinian political factions, Palestinian, and other Arab communities to a lesser extent. The focus of the Israeli's day-to-day point of concern is terrorist acts and military actions against their communities. Given the constant shelling of rockets into Israeli towns and the prevalence of suicide bombings by Palestinians and Lebanese, this concern is justified. Unlike the Israelis, the Palestinians did not necessarily feel a human security dilemma affecting their communities. The Palestinian respondents portrayed - mixed results regarding the presence of a human security dilemma. While most felt that they did not consider a human security dilemma to present, 43.8 percent of the respondents, as well as the Palestinian Ambassador to Malaysia, indicated that there exists a human security dilemma for the Palestinian community. From the government's perspective this dilemma results from the lack of a secure homeland. However, the survey respondents indicated that daily concerns for them are military actions, terrorist acts, proper access to medical care, and getting enough food to eat.

\section{-}

It is commonly accepted that most members of the same community hold a trust in one another based on the fact that they share a similar history and traditions, but this fact did

not necessarily hold true for both communities surveyed. Though the Israelis show a high
level of trust in their government and fellow Israeli citizens, the Palestinians indicated a trust level for their fellow citizens which ranged from a low level of trust to a high level of trust. While it was expected that the Palestinian individuals would indicate no trust in the Israeli government or people, it was unexpected that they would indicate a low level of trust towards the Palestinian people and only a medium level of trust towards members of their own community and the Hamas organization. As expected, the Israeli respondents indicated no trust in Hamas, with trust towards the Palestinian people and Lebanese/other Arab communities ranging from no trust to a low level of trust. Further, the Palestinian ambassador indicated that the Palestinian government held little trust in Israel's government to sincerely work towards achieving the two-state solution, and, of interest to note, the Palestinian government holds no trust in Hamas whom they see as illegally acting as the government representation in the Gaza Strip. For their part, the Israeli government does not hold a trust in the Hamas organization based on the fact that they provide no negotiation room forcing Israel to take military counter measures against these groups, which disrupts progress towards achieving the two-state solution. 
The overall lack of trust held between these communities, for and against each other, can be seen as a major contributing factor to the human security dilemma and an impediment towards achieving the two-state solution. The fact that trust for one another is lacking between these two communities, may perhaps explain why the likelihood of another conflict occurring between Israel and Palestine was indicated by most respondents as very likely to occur. From the Israeli community, the great majority of the respondents indicated that another conflict between Israel and Palestine was likely to occur within the next five years with factors such as military actions, unresolved status of the Palestinian territories, and missing persons being some of the root causes of the conflict. The respondents from the Palestinian community further felt that it was highly likely another conflict would occur between Israel and Palestine resulting from cultural difference, the - unresolved status of the Palestinian territories, military actions, poverty, and missing persons.

(1)

The two-state solution as a peace option failed to garner a majority 'yes' answer from all the respondents combined. The Palestinian respondents indicated they were unsure if the two-state solution was a viable option for peace or not, they all indicated a lack of trust in - the Israeli government, Israeli people, and cultural differences between the Arabs and the Israeli's as being factors which would disallow the two-state proposal from becoming a reality. The concern over cultural differences brought out in the Palestinian surveys is interesting as it is not a factor indicated by the Israelis as a threat or something to be concerned over. This may mean that the Israeli people do not consider that there are cultural differences between them and the Arabs, as portrayed by certain action taken by their government. It could also mean that the respondents felt it was simply not a factor that would disallow the two-state solution from occurring as they indicated a concern primarily with terrorism and the Hamas organizations, which operate using militant tactics against the State of Israel and Israeli communities. Factors that were highlighted as being necessary for the two-state solution to occur were similar amongst the Palestinians and Israeli respondents. Both the Israelis and the Palestinians indicated that the abandoning of settlements on the Gaza Strip, the West Bank, and Jerusalem was necessary, along with the demilitarization of the Palestinian territories and the removal of the Israeli military from the territories. The Palestinian respondents further indicated that the removal of the West Bank border wall, the right for the refugees to return, and the creation of an economic partnership were also necessary factors in the implementation of the two-state solution.

\section{Conclusion}

The long standing Palestine-Israel conflict is fuelled by diverse factors, ranging from the historical memory of violence, bitter disputes over the control of land, differing historical accounts, religious animosity, and constant distrust of each other have resulted in one of the bloodiest and longest conflict in the history of mankind. Military engagements against Israel by Hezbollah and Hamas have led to fierce Israeli reprisals not only against their organizations but to the civilian populations as a whole. The suffering and devastation of 
the civilian populations in Lebanon and Palestine, and in Israel, has created massive human security dilemma in these areas. In addition, the continued refusal to utilize diplomatic channels for consultation and conflict resolution has diminished the possible resolution of this conflict in the near future. Starting from an external standpoint, it is quite clear that the conflict has created extensive human insecurities in Palestine and Israel. Personal security, which refers to the safety from physical harm and abuse, is almost non-existent. Frequent skirmishes between militant groups and Israel and random attacks targeted at civilian population do not guarantee any form of personal security. Subsequently it led to other forms of insecurities, among others food security, economic security and environmental security, which are almost non-existent as well. On the other hand, internal perspective captures the sense of human security from amongst the people - who live in these conflict zones, essentially drawing from their experience and feelings of insecurities. As shown earlier, there is strong and constant fear of violence amongst Palestinian and Israeli communities. This fear has led to equally violence reprisals and hatred amongst communities, and further deterioration of conflict situation. There is a general feeling amongst the populace that sustainable living conditions can only be achieved only through cessation or termination of the conflict. However, the present - dynamics and the interacting powers in this conflict make this wish a distant reality.

\section{Notes}

1 The 2002 roadmap for peace is a plan to resolve the Israeli-Palestine conflict proposed by the United Sates, the European Union, Russia, and the United Nations. The framework of the - "roadmap for peace" is based on the concept of the two-state solution.

2 The tern "green line" is used to refer to the demarcation lines between Israel and its neighbors. During the 1967 Six-Day war Israel captured much of the territories belonging to its neighbors beyond the green line; which included the West Bank, Gaza Strip, Golan Heights (Syria), and the Sinai Peninsula (Egypt).

-

${ }^{3}$ The information within this section was obtained through a personal interview with the Palestinian Ambassador assigned to the Palestinians Consulate in Kuala Lumpur (A. Aboughosh, personal communication, 19 February 2010).

${ }^{4}$ The information within this section was obtained through a telephone interview with the Deputy Chief of Mission at the Israeli Embassy in Singapore (I Abu, personal communication, 23 March 2010). 


\section{References:}

Acharya. A. (2008). "Human Security", in Baylis, Smith, \& Owens (eds.), Globalization of world politics 4e. New York: Oxford University Press. p.493

Annan, K. (2001). "Towards a culture of peace", lecture delivered at UNESCO.

Retrieved on 5 May 2006, from

http//:www.unesco.org/opi2/letters/TextAnglais/AnnanE.html.

Faber. M.J. (2008). "Human security from below: Freedom from fear and lifeline operations", in Boer \& Wilde (eds.), The viability of human security. Amsterdam: Amsterdam University Press. p.149.

Israel Ministry of Foreign Affairs. (2001). Report to the counterterrorism committee pursuant to paragraph 6 of Security Council resolution 1373 of 28 September 2001. Retrieved on 25 September 2010, from http//:www.fas.org/irp/threat/unsc.html.

- Naruse, T. (2009). Community empowerment, regional development and platform dialogues through compressive peace building approach. Japan.

Tadjbakhsh, S. (2005). Human security: Concepts and implications. Les Etudes du CERI, p. 117-118.

Tow. W.T., and Trood, R. (2000). "Linkages between traditional security and human security." in Tow, W.T, Thakur, R., and Hyun, In- Taek (eds.,) Asia's emerging regional order: Reconciling traditional and human security. Tokyo: United Nations University Press. p. 15. 